\title{
Energy Management Strategy of a PV/Fuel Cell/Supercapacitor Hybrid Source Feeding an off- Grid Pumping Station
}

\author{
Houssem CHAOUALI (*), Hichem OTHMANI, Mohamed Selméne BEN YAHIA, Dhafer MEZGHANI and \\ Abdelkader MAMI \\ UR-LAPER, UR17ES11, Faculty of Sciences of Tunis, \\ University of Tunis El Manar, 2092 Tunis, Tunisia
}

\begin{abstract}
This work aims to develop an accurate energy management strategy for a hybrid renewable energy system feeding a pumping station. A developed model under Simulink environment is used to compare the performance of the pumping system when it is only fed by a photovoltaic generator, by a hybrid photovoltaic and fuel cell system and finally by a hybrid photovoltaic, fuel cell and a supercapacitor system. The developed control strategy is based on Fuzzy Logic control technique. Several simulations in different dramatic scenarios of working conditions show that the developed control strategy brought major enhancements in system performance and that the use of the supercapacitor makes economic profits by reducing the fuel cell production during critical solar irradiation periods.
\end{abstract}

Keywords-Energy management strategy; simulink; pumping station; photovoltaic generator; fuel cell generator; supercapacitor; fuzzy logic control technique

\section{INTRODUCTION}

In order to avoid more atmosphere pollution problems caused by conventional energy sources, scientists are continuously developing green energy sources and their applications which have touched almost every existing field such as transportation, domestic energy powering and industrial proceedings. Various environmentally friendly energy generators have been developed based on renewable energy sources, such as the sun and the wind, and although the major advantages they present, it is still impossible to avoid the dependence between this kind of power generation and weather conditions [1].

This dilemma imposed an open challenge for scientists which led to settling numerous solutions such as adding power electronics devices between the source and the load to adapt the flow between generated and requested energy. These adaptation systems are usually DC-DC converters [2], [3].

In case of an isolated, off-grid, areas where the renewable energy sources have become one of the most supplying solutions, studies focused on hybridizing different energy sources in order to ensure continuous production, so that, for example, photovoltaic (PV) generator can supply energy when wind is not available and a wind turbine can produce energy at moments of lack in solar irradiations. Of course, this hybrid settlement has many moments of zero energy production in case of absence of both wind and sun which is very common scenario during the 24 hours of the day besides the problem of the high cost that this hybrid solution would impose using two types of generators at the same moment [4]-[7].

Thanks to the invention of the Fuel Cell (FC) technology and its rapid evolution, it became a stable, efficient and clean solution for continuous power generation [8]. Proton Exchange Membrane Fuel Cell (PEMFC) is a widely used type of FCs in different sectors especially transportation such as electrical cars. So the idea of using a PEMFC as a secondary source side by side with another classical renewable energy source, such as PV generator, has been studied in numerous works such as [9]-[11]. This hybrid solution provides a continuous clean and renewable energy production without, theoretically, dependence to climate conditions.

On the other hand, the cost of energy production would be much greater because of hydrogen consumption by the FC generator, which imposes the obligation of minimizing its activation as much as possible and avoid using it as primary source. In another hand, other studies propose to include a storage device along with this hybrid type of power generation to realize the economic objective [12]-[15]. Among these proposed solutions, [16] shows a study that proves economic profits by using a supercapacitor as a secondary source in an electric car mainly fed by PEMFC.

In this context, this study is investigating the best power generation topology for our system by comparing three possible topologies where the supervision of the generators is made by using a Fuzzy Logic (FL) energy management strategy that we developed for this purpose.

In a first place, this paper gives, in Section II, a presentation and modeling of the different used generators separately: the GSA-60 PV generator, the H-500 PEMFC and the Maxwell supercapacitor.

Then, in Section III, the three-phased pumping system which is composed by a voltage inverter, an asynchronous machine and a centrifugal pump is presented and modeled.

In the last, Section IV presents the developed FL control strategy for the two investigated topologies with hybridization of sources. The simulation results are presented in order to compare the system performance with these different combinations and the PEMFC utilization. 


\section{PRESENTATION AND MODELING OF THE DIFFERENT ENERGY SOURCES}

\section{A. Photovoltaic Generator}

The main power source of the system, the photovoltaic generator, is a mixed parallel and series combination of a Kaneka GSA-060 module. In order to develop a model of this PV generator, we had to resort to the classical electrical presentation of it, shown in Fig. 1.

In another hand, Table 1 presents the different characteristics of the studied generator.

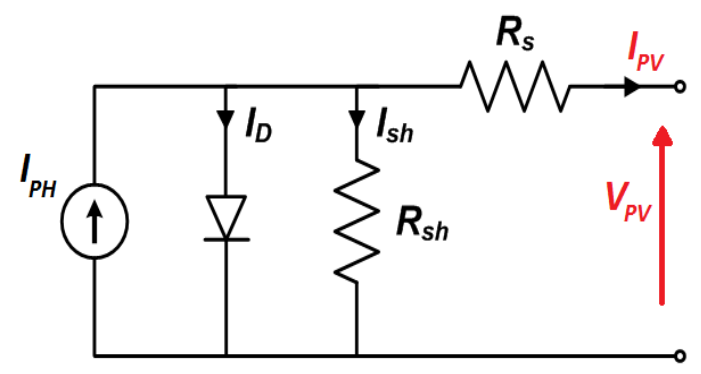

Fig. 1. Electrical presentation of a PV generator.

The generated current by the PV generator is expressed by (1): [16]

$I_{P V}=I_{P h}-I_{D}-I_{S h}$

With:

$I_{P h}=N_{P} \cdot\left[I_{C C} \frac{E}{E_{r}}+k_{i S C}\left(T-T_{r}\right) \frac{E}{E_{r}}\right]$

$I_{D}=N_{P} . I_{s}\left[\exp \left(\frac{V_{p v}}{N_{S} \cdot V_{T}}\right)-1\right]$

$I_{S h}=\frac{V_{P V}+R_{S} I_{P V}}{R_{S h}}$

$N p$ : number of parallel strings.

$N S$ : number of modules in series.

TABLE I. KANEKA GSA-60 ARRAY FEATURES

\begin{tabular}{|l|l|}
\hline Parameter & Value \\
\hline $\mathrm{Np}$ & 2 \\
\hline $\mathrm{Ns}$ & 5 \\
\hline Pmpp & $600 \mathrm{~W}$ \\
\hline Vmpp & $335 \mathrm{~V}$ \\
\hline Impp & $1.8 \mathrm{~A}$ \\
\hline Voc & $460 \mathrm{~V}$ \\
\hline Isc & $2.38 \mathrm{~A}$ \\
\hline
\end{tabular}

Fig. 2 and 3 present the I-V and P-V characteristic curves for, respectively, a variable ambient temperature and a variable solar irradiance, of 2 parallel strings of 5 in-series connected panels.
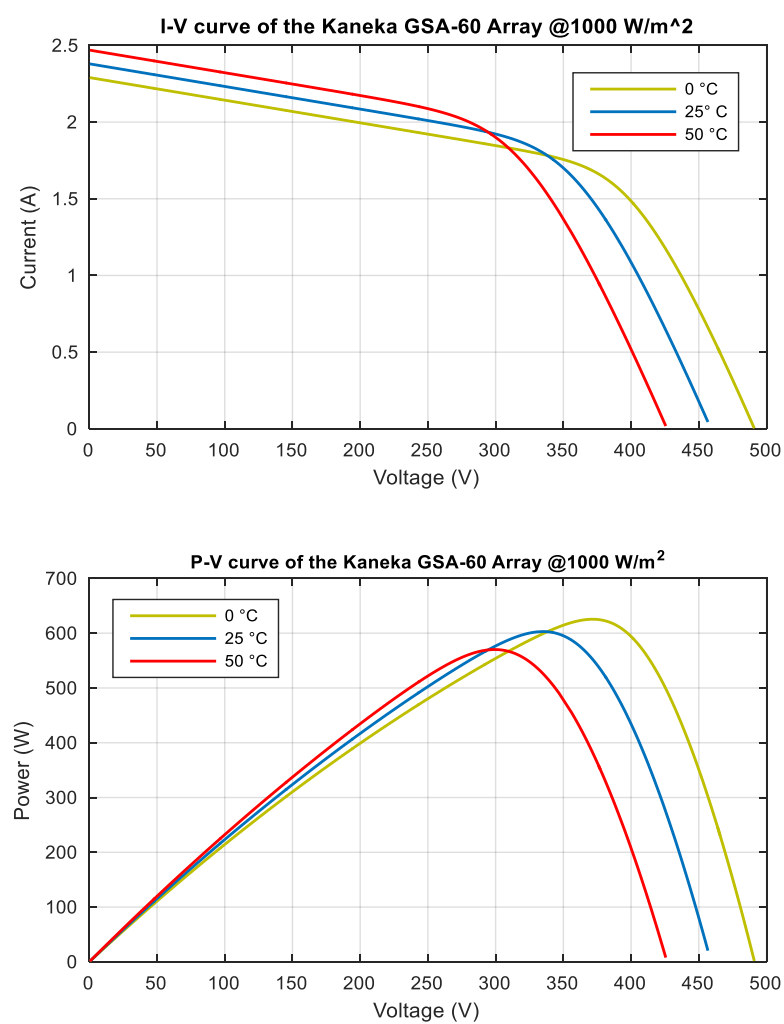

Fig. 2. The influence of ambiant temperature variation on I-V and P-V characteristics of the Kaneka GSA-60 array.
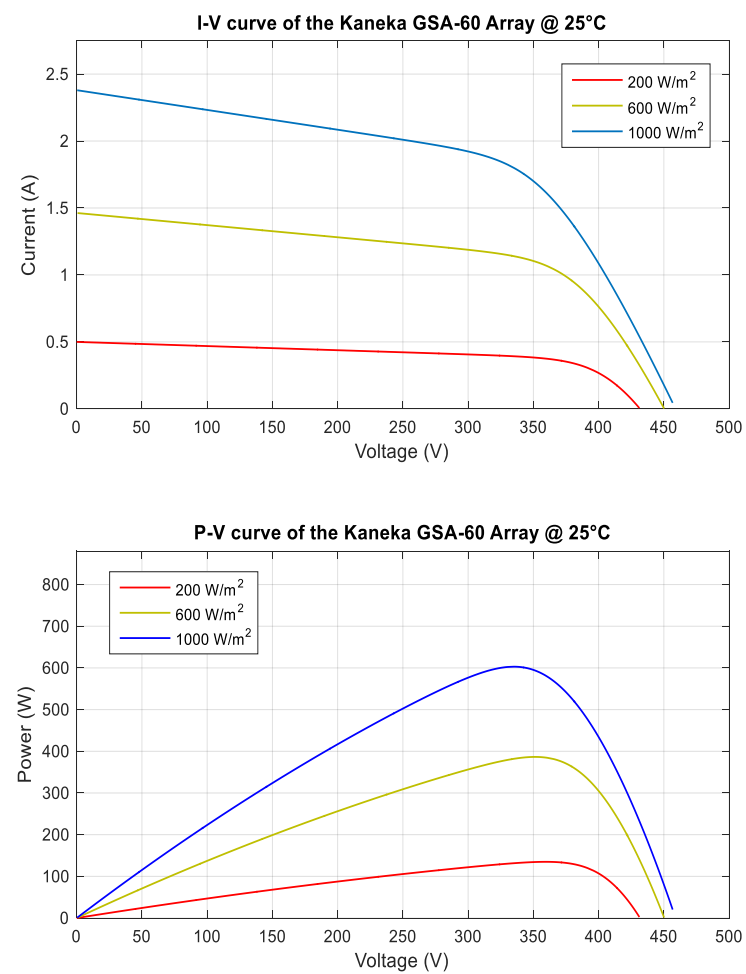

Fig. 3. The influence of solar irradiance variation on I-V and P-V characteristics of the Kaneka GSA-60 array. 


\section{B. PEM Fuel Cell}

The PEM Fuel Cells are mainly composed of three parts. These parts are the Anode, the Cathode and, between these last two seats of chemical reactions, we find a conductive membrane called the Electrolyte which is the core of the PEMFC [17].

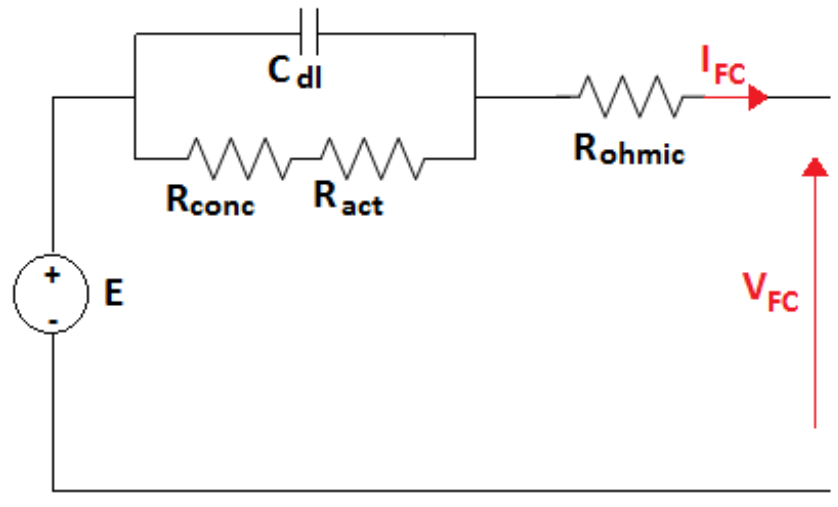

Fig. 4. PEMFC electrical circuit equivalent model.

where:

- $R_{\text {conc }}:$ concentration Resistor.

- $R_{\text {act }} \quad$ : Activation Resistor.

- $R_{\text {ohmic }}$ : Ohmoc Resistor.

- $C_{d l}$ : Double-Layer Capacitor.

Based on the electrical circuit presentation, in Fig. 4, and on Nernst equation as given in [18], [19], the PEMFC's generated voltage expression can be formulated as in (5).

$V_{F C}=E-V_{c o n}-V_{a c t}-V_{o h m}$

where:

- $V_{F C}$ : Fuel Cell Output Voltage.

- $E$ : Theoretical Potentiel of the Cell.

- $V_{c o n}$ : Gazes Concentration Voltage Losses given by (6).

- $V_{a c t}$ : Activation Voltage Losses given by (7).

- $V_{\text {ohm }}$ : Ohmic Voltage Losses given by (8).

$V_{c o n}=-\frac{R \cdot T}{2 \cdot F} \operatorname{Ln}\left(1-\frac{I_{D}}{I_{D \max }}\right)$

$V_{a c t}=\frac{R \cdot T}{2 \cdot \ell \cdot F} \operatorname{Ln}\left(\frac{I_{F C}}{I_{0}}\right)$

$V_{\text {ohm }}=I_{F C} \cdot R_{\text {ohmic }}$

Where:

- $R, T, F:$ perfect gas constant $=8.14 \mathrm{~J} / \mathrm{K} / \mathrm{mol}$

- $T$ : Operating temperature of the cell.

- $F$ : Faraday constant $=96485 \mathrm{C} / \mathrm{mol}$.

- $I_{D}, I_{D \max }$ : Current density and Current maximal density $\left(\mathrm{A} / \mathrm{cm}^{2}\right)$

- $\ell$ : Tafel slope for the activation losses.
- $I_{0}$ : Exchange current density during the activation $\left(\mathrm{mA} / \mathrm{cm}^{2}\right)$.

For this work, we chose to use a model of a 500W PEM Fuel Cell Commercialized by FuelCellsEtc under the product code H-500 which its different parameters are given in Table 2.

TABLE II. H-500 PEM FUEL CELL FEATURES

\begin{tabular}{|l|l|}
\hline Parameter & Value \\
\hline Rated Power & $500 \mathrm{~W}$ \\
\hline Number of Cells & 24 \\
\hline Rated Performance & $14.4 \mathrm{~V}$ at 35A \\
\hline Max Stack Temperature & $60^{\circ} \mathrm{C}$ \\
\hline Hydrogen Flow Rate at Maximum Output & $6.5 \mathrm{~L} / \mathrm{min}$ \\
\hline Hydrogen Pressure & $0.45-0.55 \mathrm{bar}$ \\
\hline Hydrogen Purity Requirement & $99.995 \%$ \\
\hline Start-Up Time & $<=30 \mathrm{~s}$ \\
\hline
\end{tabular}

The next figures present the different characteristics of the PEMFC model that we are using, where, Fig. 5 presents the Voltage-Current characteristic curve and Fig. 6 presents the Power-Current characteristic curve.
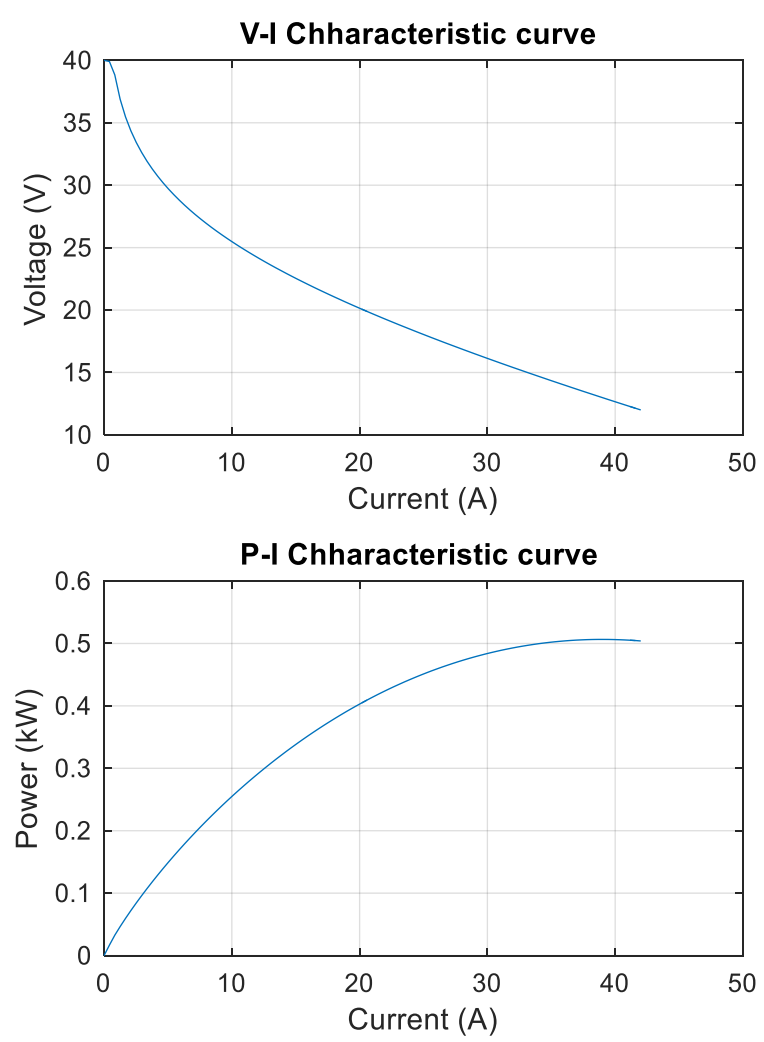

Fig. 5. V-I and P-I characteristics of the studied H-500 PEM fuel cell.

\section{Super Capacitor}

As a last energy source used in our system, the Maxwell BMOD0006-E160-B02 160V module is chosen and its different parameters are given in Table 3 . 
TABLE III. MAXWELl 160V Ultra-CAPACITOR ModUle FEATURES

\begin{tabular}{|l|l|}
\hline Parameter & Value \\
\hline Rated Capacitance & $5.8 \mathrm{~F}$ \\
\hline Rated Voltage & $160 \mathrm{~V}$ \\
\hline Maximum Voltage & $170 \mathrm{~V}$ \\
\hline Maximum Current & $170 \mathrm{~A}$ \\
\hline Maximum ESR & $240 \mathrm{~m} \Omega$ \\
\hline Maximum Stored Energy per Cell & $0.35 \mathrm{Wh}$ \\
\hline Number of Cells & 60 \\
\hline
\end{tabular}

Fig. 6 presents the discharge equivalent circuit of the supercapacitor and its mathematical model is given in (9) as in [20].

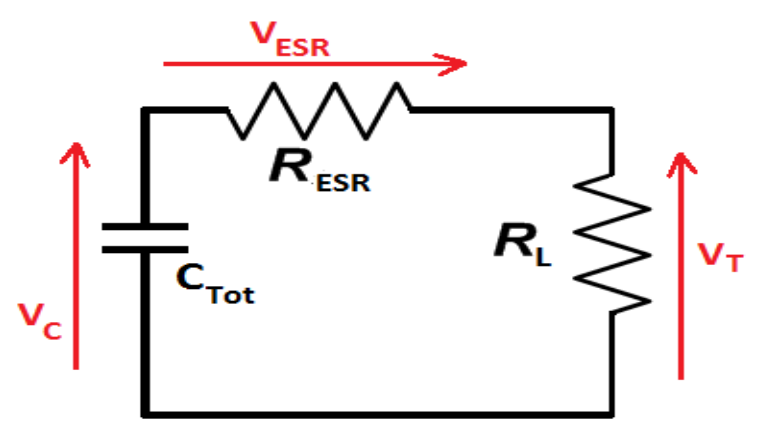

Fig. 6. Supercapacitor simplifeied dicharge electrical circuit.

$$
V_{T}(t)=V_{C}(t)+V_{E S R}(t)
$$

Where:

- $R_{E S R}=N_{S} R_{e s r}$ with $N_{S}$ is the number of cells mounted in series and $R_{e s r}$ is single cell Equivalent Series Resistance.

- $C_{\text {Tot }}=\frac{1}{N_{S}} C_{\text {Cell }}$ with $N_{S}$ is the number of cells mounted in series and $C_{C e l l}$ is single cell capacitance.

\section{PRESENTATION AND MODELING OF THE PUMPING SYSTEM}

\section{A. General Overview of the Studied Load}

The different sources we presented in the last sub-sections, are meant to supply a three-phased AC moto-pump, type Ebara Pra-050T, via a Moeller DV51 speed drive.

The speed drive, which is a three-phased inverter, is used to convert input voltage, either single phase $\mathrm{AC}$ voltage or $\mathrm{DC}$ voltage, into three-phased controllable $\mathrm{AC}$ voltages in order to control the speed of the asynchronous machine, also known as induction motor, which trains a centrifugal pump. By controlling the speed of the machine, we are controlling the flow rate of the water pumped by the moto-pump set [21].

Table 4 contains different technical specifications of both speed drive and moto-pump in study.
TABLE IV. TECHNICAL SPECS OF THE PUMPING System

\begin{tabular}{|l|l|}
\hline Moeller DV51 Speed Drive \\
\hline Maximum Power & $2.2 \mathrm{KW}$ \\
\hline AC input & $230 \mathrm{~V}$ \\
\hline DC Input & $400 \mathrm{~V}$ \\
\hline Output Voltage & $3 \sim 230 \mathrm{~V}$ \\
\hline EBara Pra-0.50T Moto-Pump \\
\hline Power & $3 \mathrm{Hp} \approx 0.37 \mathrm{Kw}$ \\
\hline Voltage & $3 \sim 240 \mathrm{~V}$ \\
\hline Nominal Current & $1.8 \mathrm{~A}$ \\
\hline Frequency & $50 \mathrm{~Hz}$ \\
\hline P & 1 \\
\hline Cos $\rho$ & 0.8 \\
\hline Maximum Speed & $2850 \mathrm{rpm} \approx 300 \mathrm{rad} / \mathrm{s}$ \\
\hline Maximum Flow rate & $45 \mathrm{~L} / \mathrm{min}$ \\
\hline
\end{tabular}

\section{B. Modeling the Different Parts of the Pumping System}

As explained, the load is composed of three different parts as shown in Fig. 7: a voltage inverter, a three-phased asynchronous machine, also called induction motor, and a centrifugal pump.

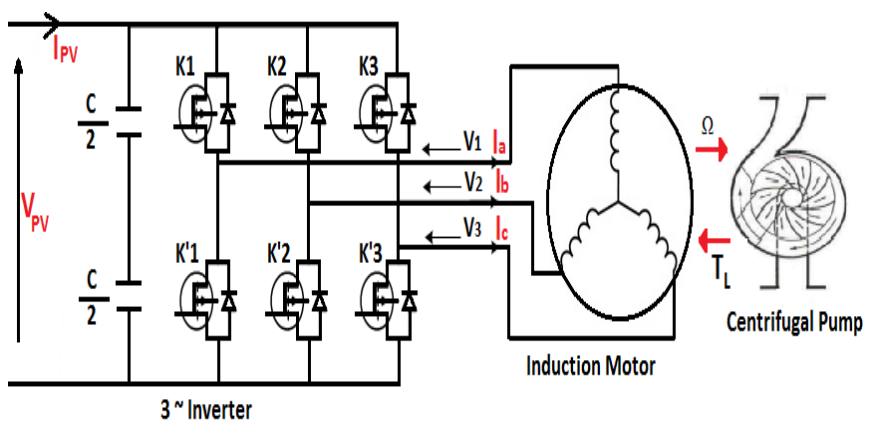

Fig. 7. 3 pumping system equivalent model.

\section{1) 3 Phased Speed Drive Modeling}

Based on this electrical scheme, the different voltages can be expressed in (10) and the relation between the input and the three output currents is given by (11) [22].

$$
\begin{aligned}
& {\left[\begin{array}{l}
V_{1} \\
V_{2} \\
V_{3}
\end{array}\right]=\frac{V_{P V}}{3}\left[\begin{array}{ccc}
2 & -1 & -1 \\
-1 & 2 & -1 \\
-1 & -1 & 2
\end{array}\right]\left[\begin{array}{l}
K_{1} \\
K_{2} \\
K_{3}
\end{array}\right]} \\
& I_{P V}=K_{1} I_{a}+K_{2} I_{b}+K_{3} I_{c}
\end{aligned}
$$

Where,

- $I_{P V}$ and $V_{P V}$ are respectively the current and voltage generated by the PV generator.

- $\mathrm{K}_{1}, \mathrm{~K}_{2}, \mathrm{~K}_{3}, \mathrm{~K}_{1}^{\prime}, \mathrm{K}_{2}^{\prime}$ and $\mathrm{K}_{3}^{\prime}$ : are the controlled switches of the 3 arms of the inverter.

\section{2) Asynchronous Moto-Pump Modeling}

The general presentation of the voltages at the stator in $d, q$ frame is given by (12) and (13) [23]. 


$$
\begin{aligned}
& V_{q s}=R_{s} \cdot I_{q s}+\frac{d \phi}{d t} \\
& V_{d s}=R_{s} \cdot I_{d s}+\frac{d \phi d s}{d t}
\end{aligned}
$$

Where,

$\phi_{q s}$ and $\phi_{d s}$ are the presentation of the stator flux in the $\mathrm{d}, \mathrm{q}$ frame given by (14) and (15).

$$
\begin{aligned}
& \phi_{q s}=L_{s} \cdot I_{q s}+M \cdot I_{q r} \\
& \phi_{d s}=L_{s} \cdot I_{d s}+M \cdot I_{d r}
\end{aligned}
$$

at the rotor of the machine, the voltage presentation is given by (16) and (17).

$$
\begin{aligned}
& V_{q r}=R_{r} . I_{q r}+\frac{d \phi q r}{d t} \\
& V_{d r}=R_{r} . I_{d r}+\frac{d \phi d r}{d t}
\end{aligned}
$$

Where,

$\phi_{q r}$ and $\phi_{d r}$ are the presentation of the rotor flux in the d,q frame given by (18) and (19).

$$
\begin{aligned}
& \phi_{q r}=L_{r} \cdot I_{q r}+M \cdot I_{q s} \\
& \phi_{d r}=L_{r} \cdot I_{d r}+M . I_{d s}
\end{aligned}
$$

The mechanical model of the machine is expressed in (20).

$$
T_{e m}-T_{L}-f \Omega=J \frac{d \Omega}{d t}
$$

Where,

$$
\begin{array}{ll}
f & : \text { Coefficient of viscous friction. } \\
J & : \text { Inertia moment. } \\
T_{e m} & : \text { Electromagnetic torque. } \\
\Omega & : \text { Rotor speed. } \\
T_{L} & \text { : Load torque. }
\end{array}
$$

The fact that the centrifugal pump presents a proportional relation between its resistive torque and the square of its speed, we can write the total electromagnetic torque of the moto-pump by replacing the new expression of $T_{L}$ in (21) and finally obtain (21) [21];

$$
T_{e m}-K \Omega^{2}-f \Omega=J \frac{d \Omega}{d t}
$$

Where, $\mathrm{K}$ is The torque constant of the pump.

\section{PROPOSED ENERGY MANAGEMENT StRATEGY}

\section{A. Fuzzy Logic Control technique}

Energy management in a system fed by hybrid power sources is important to realize an optimal energy production in term of generators life cycle (for the PEMFC), energy production cost, total and instantaneous cover of energy demand, etc. [16].

For that, numerous techniques have and still been used to achieve these different objectives. Among them, intelligent controllers such as FLC technique is presented as a reliable choice for this mission because since its first appearance in 1965, by Lotfi Zadeh, it witnessed rapid development and replaced almost all conventional techniques a wide range of applications [24].

A general working principle of an FLC based on Mamdani method is given by its flow chart in Fig. 8 [25].

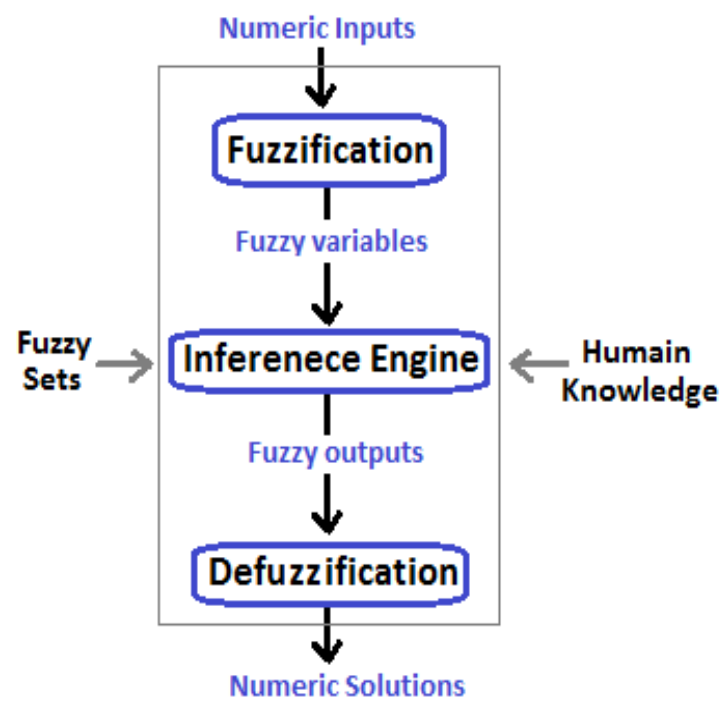

Fig. 8. Mamdani FLC working flow chart.

\section{B. Developed FLC for Energy Management}

We developed a management strategy based on FLC technique for two proposed topologies to compare the results. The difference between the two topologies is the existing of the supercapacitor in order to investigate its role in minimizing the PEMFC power generation, and thus, hydrogen consumption and total power production cost [16].

\section{1) Topology 1: Standard PV-Pumping System}

This topology is the standard system in study. It is composed of the PV generator supplying the load via the different converters and their controllers (MPPT and Speed).

\section{2) Topology 2: Without Supercapacitor}

This topology contains two energy sources, PV generator and the PEM fuel cell, and the load. The developed fuzzy algorithm for energy management in this topology uses two inputs given in (22) and (23) in order to determine the output which is one of the predefined modes in order to select the proper working configuration of the system. 


$$
\begin{aligned}
& P_{\text {demand }}=P_{P V}-P_{L o a d} \\
& d P_{\text {demand }}=P_{\text {demand }}(k)-P_{\text {demand }}(k-1)
\end{aligned}
$$

The different modes of system configuration are explained as next:

- Mode 1: The GPV is the only energy source and the PEMFC is not connected.

- Mode 2: The PEMFC is activated and the GPV is not connected.

- Mode 3: The GPV and PEMFC are both activated and must make sure that the GPV is the main generator and the PEMFC only works to compensate the lack of energy demanded by the load.

\section{3) Topology 3 : with Supercapacitor}

This topology contains the two energy sources, PV generator and the PEM fuel cell, along with the storage device, the supercapacitor, and the three-phased pumping system. The developed fuzzy algorithm for energy management in this topology uses an additional 3rd input which is the State Of Charge (SOC) of the supercapacitor besides the same two inputs previously given by (22) and (23) in order to determine the proper working mode and thus selecting the optimal working configuration of the system.

Different modes of system configuration are set as next:

- Mode 1: The GPV is the only energy source, the PEMFC and the Supercapacitor are not connected.

- Mode 2: The GPV is activated, the Supercapacitor is charging (condition: SOC $<50 \%$ ) and the PEMFC is not connected.

- Mode 3: The GPV is activated, the Supercapacitor is discharging (condition: $\mathrm{SOC}>50 \%$ ) and the PEMFC is not connected.

- Mode 4: The GPV is activated, the Supercapacitor is discharging (condition: $\mathrm{SOC}>50 \%$ ) and the PEMFC is activated.

All the modes must maintain these conditions: The main source must be the GPV, the supercapacitor only charges when the GPV power exceeds the demanded power, the PEMFC is only activated when the GPV power is not enough for load demand and the supercapacitor is discharged.

\section{Results and Discussion}

Fig. 9 shows the speed response with different studied topologies in constant irradiance equal to $1000 \mathrm{~W} / \mathrm{m} 2$.

Fig. 10 shows the speed response with different studied topologies in variable irradiance where the imposed simulation scenario is:

- From $\mathrm{t}=0 \mathrm{~s}$ to $\mathrm{t}=5 \mathrm{~s}$ : constant at $1000 \mathrm{~W} / \mathrm{m}^{2}$.

- At $\mathrm{t}=5 \mathrm{~s}$ : variation from $1000 \mathrm{~W} / \mathrm{m}^{2}$ to $200 \mathrm{~W} / \mathrm{m}^{2}$.

- From $\mathrm{t}=5 \mathrm{~s}$ to $\mathrm{t}=10 \mathrm{~s}$ : constant at $200 \mathrm{~W} / \mathrm{m}^{2}$.
- At $\mathrm{t}=10 \mathrm{~s}$ : sudden variation of irradiance from $200 \mathrm{~W} / \mathrm{m}^{2}$ to $800 \mathrm{~W} / \mathrm{m}^{2}$.

- From $\mathrm{t}=10 \mathrm{~s}$ to $\mathrm{t}=15 \mathrm{~s}$ : constant at $800 \mathrm{~W} / \mathrm{m}^{2}$.

Fig. 9 and 10 proves that topology 3 has better performance in both variable and constant irradiance conditions.

Fig. 11 presents the on/off status of the PEMFC with both topologies 2 and 3 in the case of variable irradiance.

The obtained results show that even for a high irradiance $\left(1000 \mathrm{~W} / \mathrm{m}^{2}\right)$, there has been a frequent activation of the PEMFC in topology 2 and a continuous activated status in low irradiance value. In another hand, with topology 3 , the PEMFC has not been activated even when the irradiance is at 200 $\mathrm{W} / \mathrm{m}^{2}$.

This can be explained by the fact that the GPV can deliver the needed power by itself when the irradiance is high and the supercapacitor, initially charged at $100 \%$, would deliver the additional needed power when the irradiance is low.

Fig. 12 presents the evolution of SOC of the Supercapacitor initially charged. At the start, even the irradiance is high, the SOC makes a quick drop because of the nature of the load which demands more energy in its starting phase. Then, we can see clearly that during the low irradiance period, the supercapacitor is discharging to provide the difference between the generated power by the PV generator and load demand. After that, when the irradiance reaches high values in a second time, the supercapacitor is charging and its SOC is rising.

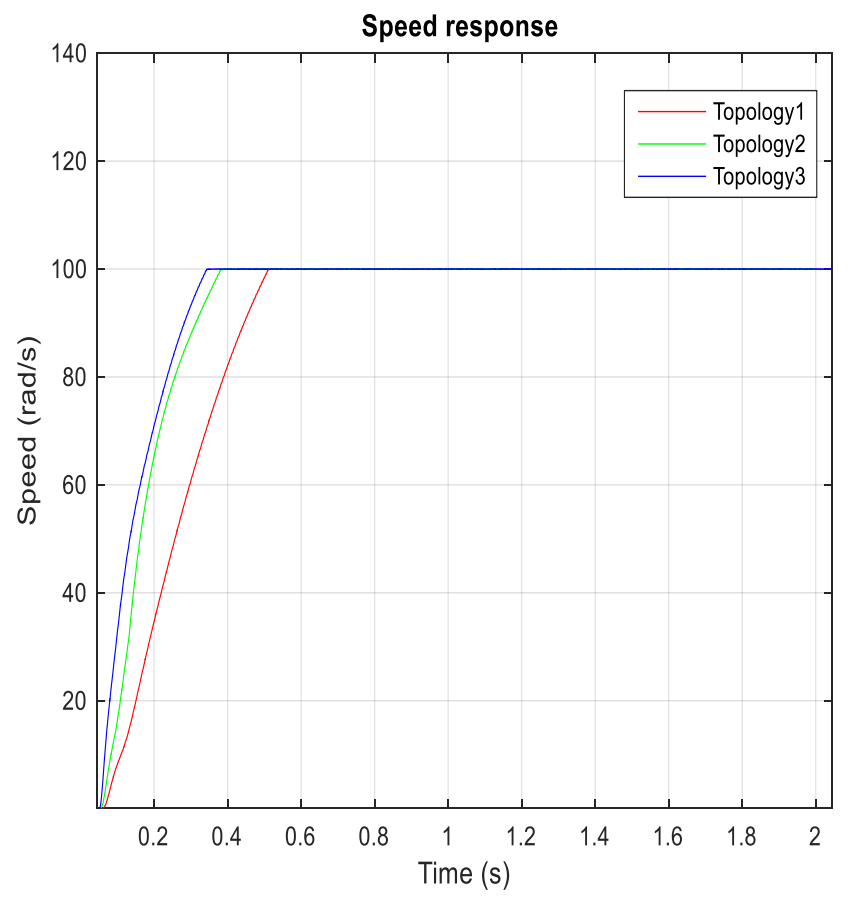

Fig. 9. Speed response with different topologies for constant irradiance. 


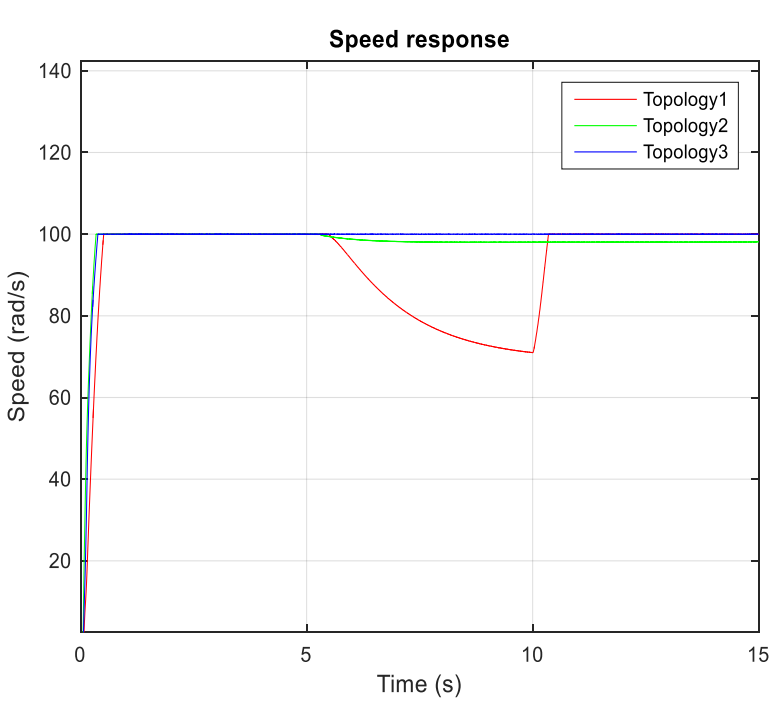

Fig. 10. Speed response with different topologies for variable irradiance.

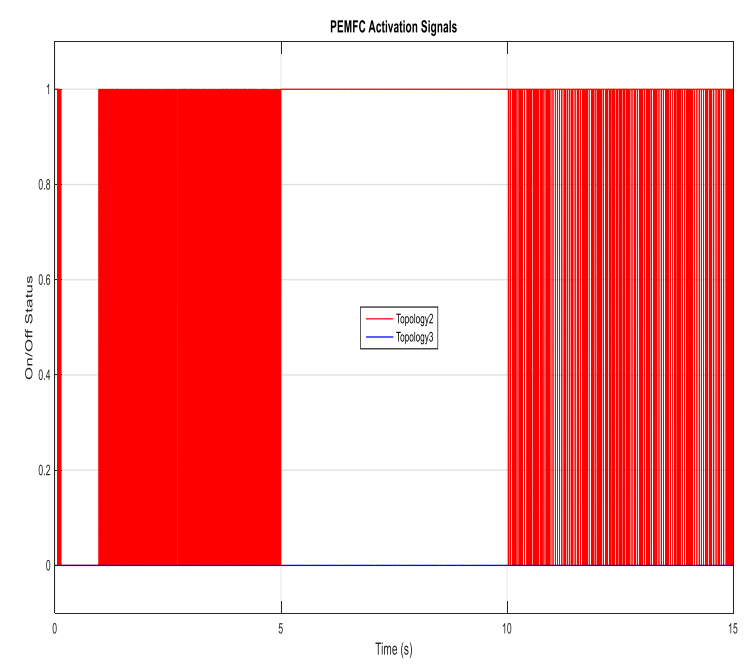

Fig. 11. PEMFC activation signal for a variable irradiance.

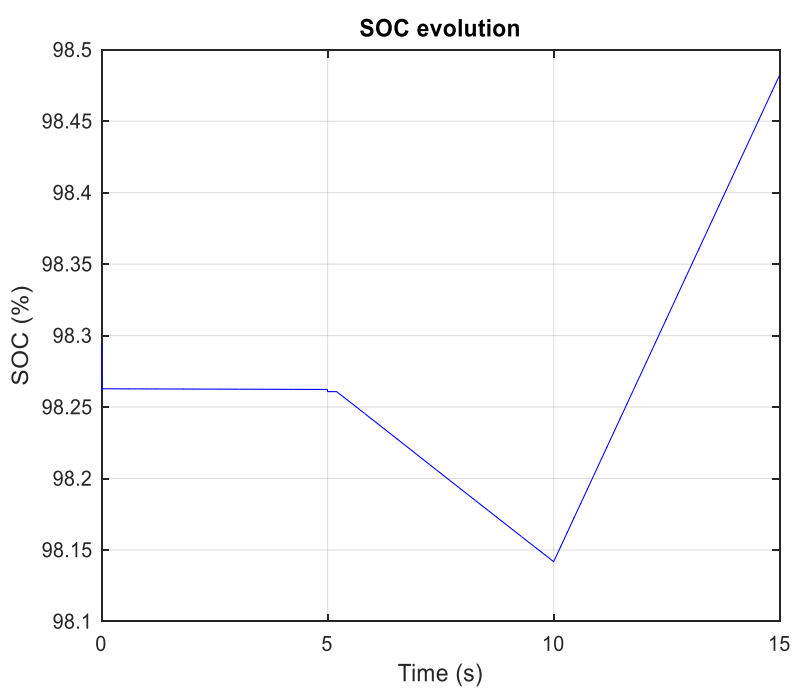

Fig. 12. SOC evolution of the super capacitor initially charged.

\section{CONCLUSION}

The different results show a better performance of the system, when using the topology with photovoltaic generator, PEMFC and supercapacitor, in both constant and variable irradiance and a major economic profit because of the supercapacitor charge/discharge cycles supervision in by the Fuzzy Logic management strategy.

This work can be enhanced by adding Lithium Batteries bank to have a hybrid storage system which will ensure that the utilization of the PEMFC will be reduced even in long periods of solar irradiance absence, and thus less fuel consumption. In the control side, the management strategy can be based on Economic Model Predictive Control (EMPC) technique which is a new developed form of the classic MPC control technique. The investigation of the system performance by using this new storage scheme and control approach will make the subject of future works.

\section{REFERENCES}

[1] M. H. Nehrir, C. Wang, K. Strunz, H. Aki, R. Ramakumar, J. Bing, Z. Miao, and Z. Salameh, "A review of Hybrid Renewable/Alternative Energy Systemsfor Electric Power Generation: Configurations, Control, and Applications", IEEE Transactions On Sustainable Energy, 2(4) , pp. 392-403, November 2011. http://dx.doi.org/10.1109/TSTE.2011.2157540

[2] JABALLAH Mohamed Akram, MEZGHANI Dhafer and MAMI Abdelkader, "Design and Simulation of Robust Controllers for Power Electronic Converters used in New Energy Architecture for a (PVG)/ (WTG) Hybrid System", International Journal of Advanced Computer Science and Applications(IJACSA), 8(5),

2017. http://dx.doi.org/10.14569/IJACSA.2017.080531

[3] CHAOUALI Houssem,OTHMANI Hichem, MEZGHANI Dhafer, JOUINI Houda and MAMI Abdelkader, "Fuzzy logic control scheme for a 3 phased asynchronous machine fed by Kaneka GSA-60 PV panels", IEEE International Renewable Energy Congress(IREC), Tunisia 2016. https://doi.org/10.1109/IREC.2016.7478893

[4] KAABECHE Abdelhamid and IBTIOUEN Rachid, "Techno-economic optimization of hybrid photovoltaic/wind/diesel/battery generation in a stand-alone power system”, Solar Energy, 103, pp. 171-182, 2014.

https://doi.org/10.1016/j.solener.2014.02.017

[5] Binayak Bhandari, Kyung-Tae Lee, Caroline Sunyong Lee, Chul-Ki Song, Ramesh K. Maskey and Sung-Hoon Ahn, "A novel off-grid hybrid power system comprised of solar photovoltaic, wind, and hydro energy sources", Applied Energy, 133, pp. 236-242, 2014 https://doi.org/10.1016/j.apenergy.2014.07.033

[6] Ajay Kumar Bansal, Rajesh Kumar and R. A. Gupta, "Economic analysis and power management of a small autonomous hybrid power system (SAHPS) using biogeography based optimization (BBO) algorithm", IEEE Transactions on Smart Grid, 4(1), pp. 638-648, 2013. http://dx.doi.org/10.1109/TSG.2012.2236112

[7] Lei Zhang and Yaoyu Li, "Optimal Energy Management of WindBattery Hybrid Power System With Two-Scale Dynamic Programming", IEEE Transactions on Sustainable Energy, 4(3), pp. 765-773, 2013. https://doi.org/10.1109/TSTE.2013.2246875

[8] R. Chedid, H. Akiki, and S. Rahman, "A decision support technique for the design of hybrid solar-wind power systems," IEEE Transactions on Energy Conversion, vol 13(1), pp. 76-83, 1998.

[9] PASKA Józef, BICZEL Piotr and K1OS Mariusz, "Hybrid power systems - An effective way of utilising primary energy sources", Renewable Energy, 34(11) pp. 2414-2421, 2009. https://doi.org/10.1016/j.renene.2009.02.018

[10] Mehmed Eroglu, Erkan Dursun, Suat Sevencan, Junseok Song, Suha Yazici and Osman Kilic, " A mobile renewable house using 
PV/wind/fuel cell hybrid power system", International Journal of Hydrogen Energy, 36(13), pp. 7985-7992, 2011.

https://doi.org/10.1016/j.ijhydene.2011.01.046

[11] O.C. Onar, M. Uzunoglu, M.S. Alam and Dynamic modelling, "Design and Simula-Tion of a Wind/Fuel Cell/Ultra-Capacitor-Based Hybrid Power Generation System", Journal of Power Sources, 61(1), pp. 707722, 2006.

https://doi.org/10.1016/j.jpowsour.2006.03.055

[12] Phatiphat Thounthong, Arkhom Luksanasakul, Poolsak Koseeyaporn and Bernard Davat, "Intelligent Model-Based Control of a Standalone Photovoltaic/Fuel Cell Power Plant With Supercapacitor Energy Storage", IEEE Transactions on Sustainable Energy, 4(1), pp. 240-249, 2013.

http://dx.doi.org/10.1109/TSTE.2012.2214794

[13] Akbar Maleki and FathollahPourfayaz, "Sizing of stand-alone photovoltaic/wind/diesel system with battery and fuel cell storage devices by harmony search algorithm", Journal of Energy Storage, 2, pp.30-42, 2015.

https://doi.org/10.1016/j.est.2015.05.006

[14] Hassan El Fadil, Fouad Giri, Josep M. Guerrero and Abdelouahad Tahri, "Modeling and Nonlinear Control of a Fuel Cell/Supercapacitor Hybrid Energy Storage System for Electric Vehicles", IEEE Transactions on Vehicular Technology, 63(7), pp. 3011 - 3018, 2014. http://dx.doi.org/10.1109/TVT.2014.2323181

[15] MehdiAnsarey, Masoud Shariat Panahi, Hussein Ziarati and Mohammad Mahjoob, "Optimal energy management in a dual-storage fuel-cell hybrid vehicle using multi-dimensional dynamic programming", Journal of Power Sources, 250, pp. 359-371, 2014.

https://doi.org/10.1016/j.jpowsour.2013.10.145

[16] ANDARI Wahib, GHOZZI Samir, ALLAGUI Hatem and MAMI Abdelkader, "Design, Modeling and Energy Management of a PEM Fuel Cell / Supercapacitor Hybrid Vehicle" International Journal of Advanced Computer Science and Applications(IJACSA), 8(1), 2017. http://dx.doi.org/10.14569/IJACSA.2017.080135

[17] BEN SALEM W., MZOUGHI D., ALLAGUI H. and MAMI A., "The bond graphs to the study of interactions between the PEM fuel cell and static converters", 17th International Conference on Sciences and Techniques of Automatic Control and Computer Engineering (STA), pp.423-428, Tunisia 2016.

http://dx.doi.org/10.1109/STA.2016.7952004

[18] BEN YAHIA Mohamed Sélmene, ALLAGUI Hatem, BOUAICHA
Arafet and MAMI Abdelkader, "Fuel Cell Impedance Model Parameters Optimization using a Genetic Algorithm", International Journal of Electrical and Computer Engineering(IJECE), 7(1), pp. 184-193, 2017.

[19] ALLAGUI Hatem, MZOUGHI Dhia, BOUAICHA Arafet and MAMI Adelkader, "Modeling and Simulation of $1.2 \mathrm{~kW}$ Nexa PEM Fuel Cell System", Indian Journal of Science and Technology, 9(9), 2016. http://dx.doi.org/10.17485/ijst/2016/v9i9/85299

[20] A. B. Cultura II, Z. M. Salameh, "Modeling, Evaluation and Simulation of a Supercapacitor Module for Energy Storage", International Conference on Computer Information Systems and Industrial Applications (CISIA 2015), Thailand 2015.

[21] MEZGHANI Dhafer, OTHMANI Hichem, SASSI Fares, MAMI Abdelkader and DAUPHIN-TANGUY Geneviève, "A New Optimum Frequency Controller of Hybrid Pumping System: Bond Graph Modeling-Simulation and Practice with ARDUINO Board" International Journal of Advanced Computer Science and Applications(IJACSA), 8(1), 2017. http://dx.doi.org/10.14569/IJACSA.2017.080112

[22] MEZGHANI Dhafer, OTHMANI Hichem, SASSI Fares, MAMI Abdelkader and G. Dauphin-Tanguy, "A New Optimum Frequency Controller of Hybrid Pumping System: Bond Graph ModelingSimulation and Practice with ARDUINO Board", International Journal of Advanced Computer Science and Applications(IJACSA), 8(1), pp. 78-87, 2017. http://dx.doi.org/10.14569/IJACSA.2017.080112

[23] OTHMANI Hichem, SASSI Fares, MEZGHANI Dhafer and MAMI Abdelkader, "Comparative Study between Fuzzy Logic Control and Sliding Mode Control for Optimizing the Speed Deportment of a Three Phase Induction Motor", International Review of Automatic Control, 9(3), pp. 175-181, 2016.

https://doi.org/10.15866/ireaco.v9i3.9269

[24] N. Ammasai Gounden, Sabitha Ann Peter, Himaja Nallandula, S.Krithiga, "Fuzzy logic controller with MPPT using line-commutated inverter for three-phase grid-connected photovoltaic systems", Renewable Energy, 34(3), pp. 909-915, 2009. http://dx.doi.org/10.1016/j.renene.2008.05.039

[25] Houssem Chaouali, Hichem Othmani, Dhafer Mezghani and Abdelkader Mami, "Enhancing classic IFOC with Fuzzy Logic technique for speed control of a 3 Ebara Pra-50 moto-pump", 17th International Conference on Sciences and Techniques of Automatic Control and Computer Engineering (STA), pp.423-428, Tunisia 2016. http://dx.doi.org/10.14569/10.1109/STA.2016.7951985 